\title{
Transitions between risk management regimes in cities
}

\author{
$\underline{\text { William Solecki }}^{1}$, Mark Pelling $^{2}$ and Matthias Garschagen $^{3}$
}

\begin{abstract}
Ongoing climate change is encouraging cities to reevaluate their risk management strategies. Urban communities increasingly are being forced to respond to climate shifts with actions that promote resistance, resilience, or even larger scale transformations. Our objective is to present a conceptual framework that facilitates examination of how the transition from one type of risk management strategy or regime to another takes place. The research framework is built around a set of assumptions regarding the process of transition between risk management regimes. The framework includes five basic conceptual elements: (1) risk management regimes, (2) development pathways, (3) activity spheres, (4) activity spaces, and (5) root, contextual, and proximate drivers. The interaction among these elements and the potential for transition between four different possible regime states including resistance, resilience, transformation, and collapse are presented. The framework facilitates and guides analysis on whether and how transition is emergent, constrained, or accelerated in specific contexts. A case study of post-Hurricane Sandy New York is used to illustrate the framework and its overall effectiveness.
\end{abstract}

Key Words: resiliency; risk management; transformation; transitions; urban coasts

\section{INTRODUCTION}

As New Yorkers, we cannot and will not abandon our waterfront. It's one of our greatest assets. We must protect it, not retreat from it. Mayor Bloomberg, announcing the Special Initiative on Rebuilding and Resiliency after Hurricane Sandy, 11 June 2013.

The intersection of climate change with urban development imperatives and demographic trends places risk management not only as a mechanism to protect development gains but also, as an increasingly pronounced component in social struggles between competing values and visions for the city (Pelling 2011, Pelling et al. 2012, Solecki et al. 2013, Wise et al. 2014, Garschagen and Romero-Lankao 2015). How risk is managed in the city will in no small part shape the future city, the distribution of risks and opportunities it offers citizens, nature and capital (O'Brien 2012, Pelling and Blackburn 2013, Pelling et al. 2015), and the prospects for sustainability (Olsson et al. 2014).

Ongoing climate change and urban development pressure will create opportunities for frequent reappraisal and change of natural hazard risk management in cities. The central goal of this paper is to specifically examine how urban risk management policies and programs change under these dynamic conditions, and their potential directions of change. Our specific focus is on the process and context of what we describe as risk management transitions. We present a conceptual framework that is designed to allow for greater understanding of such transitions, which are articulated through popular and policy discourse, administrative and legislative structures, and practical on-the-ground actions and impacts. The approach and framework are validated through case examples drawn from the post-Hurricane Sandy period in New York City. ${ }^{[1]}$ The framework argues that competing risk management regimes, i.e., an assemblage of policies, strategies, and regulations that collectively define a dominant paradigmatic management approach (for examples and more discussion see
May and Jochim 2013), can be observed in any moment within a city, and that these regimes are a product of climate risk and urban development pressures and in turn will mediate their interaction.

We define four different regimes along a gradient of increasing breadth in policy choices for managing the adaptationdevelopment nexus (Garschagen, Pelling, Solecki, et al., unpublished manuscript), from collapse to resistance, resilience, and transformation. Urban development is seen here as composed of social, economic, and political structures and individual choices made material through physical construction and land use. It is often the case that in market-based economies, a consortium of political and business elite whose interests are mediated through public policy, property rights, and legal protections drives urban development in cities (Logan and Molotch 1987).

Understanding and facilitating transitions between risk management regimes is of key importance if the adaptationdevelopment nexus is to be articulated and managed with the fullest range of possible policy options within particular risk and governance contexts. In an era of dynamic climatic, demographic, and socio-political drivers, planning for sustainability is as much about recognizing and anticipating transitions as it is about maximizing existing regime policy space (Pahl-Wostl 2007).

We consider the proposed framework as a way to explore current movement and the potential directions of current and future transitions. As presented, it is not a strongly historical framework through which one could draw out past rounds of transition. Our focus here is on engaging with the current context and current decision makers. ${ }^{[2]}$ The framework is structured to provide a clear diagnosis of the contemporary risk management regime within which one can situate tendencies and constraints for policy shifts (if any) and then potential directions of movement that might occur at one or multiple levels of management and be contradictory. ${ }^{[3]}$ 
The conceptualization of each regime system state and of transition from one state to another draws from political ecology work in natural hazards, urban development theory, complex system theory, and resiliency theory. The result is a hybrid lexicon bringing the advantage of allowing ideas and terms sensitive to actor, structure, and system to be brought together. This requires care because different epistemologies at times deploy common terms with divergent meanings. These instances are flagged below. Overall, the paper is organized into five sections: the core elements of risk management regimes and system transitions, the risk management transition approach, illustrative case material from New York City discussion and analysis with a concluding statement.

\section{FOUR RISK MANAGEMENT REGIMES}

A risk management regime is presented as an established set of institutions, norms, and behaviors organized in such a way to promote an entrenched pattern of disaster risk preparedness, response, and recovery. Embedded in each risk management regime is a set of assumptions and assertions regarding the conceptualization of risk, the rights and responsibilities of the state and other actors, the mode of risk governance, and the underlying issues of equity and fairness. Here four archetypal risk management regimes are defined that reflect a set of intended and unintended practices: collapse, resistance, resilience, and transformation. We specify these terms and associated concepts from an extensive review of literature (Rotberg 2011 and Douglas et al. 2015 on analyses of systems under conditions of collapse; Folke et al. 2010, Schlüter and Herrfahrdt-Pähle 2011, Wilson et al. 2013, Hordijk et al. 2014 on resilience and the connective transformability; Brown et al. 2013, Ferguson et al. 2013, McApline et al. 2015 on the concept of transformation and diagnosing transformative change; Binder et al. 2013, Polechová and Barton 2015 on the use of different frameworks for analyzing social-ecological systems; Hodbod and Adger 2014 on how to connect resiliency to management system analysis).

It should be noted that the terms collapse, resistance, resilience, and transformation remain debated terms in the wider socialecological systems and political ecology literature (Cote and Nightingale 2012). The framework stays close to the definition of the terms articulated in social-ecological systems (SES) literature with some augmentation and synthesis with ideas from political ecology. Past use of integrative approaches to SES and political ecology has successfully sharpened analytical rigor especially around questions of power, for example where SES has been in conversation with Gidden's structuration theory (Pelling and Manuel-Navarrete 2011) or Harvey's activity space theory (Pelling et al. 2015). Closest to SES thinking are resilience (flexibility at the margins) and transformation (fundamental change). More hybridized are the terms collapse and resistance.

A resilient regime is able to adjust flexibly in the anticipation or experience of a hazard (Adger et al. 2005). A resilient system's functions and core aims are maintained with only slight adjustment, though these may be significant for subsystems or over time. In social systems, an example of significant impact will be adjustments to property insurance rates that allow continued habitation in places of risk through changes in payment rates. In contrast to resistant systems, resilient systems can anticipate, absorb, accommodate, or recover from the effects of a hazardous event in a timely and efficient manner through preservation, restoration, or improvement of the system's essential basic structures and functions. Essentially, the system responds by accepting loss and returning to its preshock/stress state, which in turn may be perceived by dominant actors as the preferred state (Pelling 2011). However, although resiliency planning typically aims at facilitating the survival of the system despite stress and hazards, the configuration of the system as such and its long-term sustainability are typically not fundamentally called into question by local stakeholders (Garschagen 2013), in contrast to the transformation state (Bahadur and Tanner 2014). It should be noted that resistant and resilient states may lead to similar levels of disaster risk reduction over the short term, ceteris paribus.

A transformative management regime identifies, and is open to the need for significant change in fundamental development trends in order to avoid unacceptable risk and future loss (O'Brien 2012). This can involve concerns over distributional as well as overall loss. Including management systems for transformation, once resilience limits and barriers are met, can open a range of new policy options for mangers (Pelling et al. 2015). Transformation also can target the root drivers of unmet sustainable development needs that may constrain adaptive capacity and action (Pelling 2011, Marshall et al. 2012). Furthermore, intentional transformation of one system or object can allow for the maintenance of systems at other scales. As example, relocation of households exposed to risk will be transformative for households involved, for places of origin and destination, and could require legislative change. At the same time, relocation might help maintain resilience or resistance in wider political and economic or social systems. Transformation implies the widest array of possible adaptation and policy options of all four regimes. Whereas resistance, for instance, is typically oriented toward protecting given systems against new hazards through persistence, transformation is more open and can in principle include a wide diversity of measures such as the board protection, accommodation, and withdrawal, e.g., retreat from coastal areas increasingly made vulnerable by sea level rise. ${ }^{[4]}$

Collapse is used in both SES and political ecology traditions to describe a regime or system where transparent and accountable coordinating structures have ceased to function or are otherwise missing. In SES, the adaptive cycle (Holling et al. 2002) uses collapse to describe systems experiencing periods of structural fragmentation and implies these lie between more enduring states of stability. Political ecology accepts that fragmentation and lack of coordinating structures could endure and indicate a stability state in their own right. Collapsed regimes are those that suffered from severe dysfunction and chaos and offer advantage to some political-economic actors (Pelling 2003), providing impetus for the durability of collapse. Collapsed regimes can include those where government authority has failed leading to anarchic, deeply conflicted, and dangerous outcomes (Rotberg 2011), and also more benign contexts where state power is absent and autonomous capacity is unhindered by violence though remains uncoordinated.

Resistance indicates a determination to protect the stability of economic life in the city, i.e., the impacts of climate change are to be resisted. This draws from Holling's (1973) description of stability in which a system is configured to maintain its state. As 
Table 1. Risk management characteristics, causes, and potential consequences of each regime.

\begin{tabular}{|c|c|c|c|c|}
\hline & Collapse & Resistance & Resilience & Transformation \\
\hline Characteristics of Regime & $\begin{array}{l}\text { No sufficient response or } \\
\text { adjustment to drivers of } \\
\text { risk, including increasing } \\
\text { hazard frequency and } \\
\text { intensity as well as soaring } \\
\text { exposure, susceptibility, and } \\
\text { lack of coping capacity. }\end{array}$ & $\begin{array}{l}\text { Directed toward shielding } \\
\text { existing or future systems } \\
\text { and urban developments } \\
\text { against the intensifying } \\
\text { hazards without changing } \\
\text { the urban system } \\
\text { configuration as such. }\end{array}$ & $\begin{array}{l}\text { Flexible system adjustments } \\
\text { in response to anticipated or } \\
\text { manifest hazards, without, } \\
\text { however, putting the core of } \\
\text { the system configuration as } \\
\text { such into question. }\end{array}$ & $\begin{array}{l}\text { Fundamental change in the } \\
\text { system configuration is } \\
\text { deemed necessary and } \\
\text { implemented, putting the core } \\
\text { of formerly established } \\
\text { system configurations into } \\
\text { question. }\end{array}$ \\
\hline Causes & $\begin{array}{l}\text { Can be driven by incapacity } \\
\text { or inactivity, both of which } \\
\text { can be caused by either or a } \\
\text { lack of awareness, resources, } \\
\text { or power to change the } \\
\text { regime. }\end{array}$ & $\begin{array}{l}\text { Persistence of the existing } \\
\text { system configuration is the } \\
\text { uncompromised goal; } \\
\text { alternative development } \\
\text { pathways are not conceived, } \\
\text { considered necessary, or } \\
\text { possible because of limited } \\
\text { awareness, resources, or } \\
\text { power. }\end{array}$ & $\begin{array}{l}\text { Acknowledgement that some } \\
\text { system change will be } \\
\text { necessary to facilitate the } \\
\text { survival of the system and } \\
\text { the capacity (resources, } \\
\text { power, know-how) to act on } \\
\text { this insight. }\end{array}$ & $\begin{array}{l}\text { Can be driven proactively in } \\
\text { anticipation of otherwise } \\
\text { insurmountable hazard stress } \\
\text { or reactively in response to } \\
\text { loss, damage, or even collapse }\end{array}$ \\
\hline Potential consequence $^{\dagger}$ & $\begin{array}{l}\text { Increasing stress and } \\
\text { hazards might render the } \\
\text { persistence of the urban } \\
\text { system impossible, leading to } \\
\text { collapse. }\end{array}$ & $\begin{array}{l}\text { Increasing need for resources } \\
\text { to keep up resistance; might } \\
\text { eventually prove } \\
\text { unsustainable and lead to } \\
\text { collapse regimes. }\end{array}$ & $\begin{array}{l}\text { Increase in the midterm } \\
\text { ability of the system to } \\
\text { survive but open outcomes if } \\
\text { hazards and stress intensify } \\
\text { further in the long term. }\end{array}$ & $\begin{array}{l}\text { Embarking on fundamentally } \\
\text { new development pathway } \\
\text { and risk governance } \\
\text { principles. }\end{array}$ \\
\hline
\end{tabular}

${ }^{\top}$ Theoretically each risk management regime could result in collapse depending on the circumstances and time frame.

Holling notes, stability may be desirable where hazards are mild, but failure to adjust systems configurations if hazard and risk intensities increase is dangerous for systems' survival. Systems unable to transition from stability may be at risk of catastrophic failure. Handmer and Dovers (1996) use resistance to describe regimes where risk may be denied with resources being invested to support existing institutions and authorities. When risk is undeniable these regimes typically delay action by a call to greater scientific research before action is possible. Handmer and Dovers (1996) identify resistance with authoritarian political contexts where access to information is controlled. Resistance, often associated with conventional, engineered infrastructure-focused management, may require major shifts and investment in nonprioritized or external elements, so that resistance in one system may require collapse or transformation in another. For example, the construction of increasingly large and complex coastal defenses to prevent any change in function, value, or vision of coastal land may transform nearshore ecology and livelihoods or downstream hazards. Resistant systems could expend considerable resources on preventing change by attempting to manage external environment stressors.

We use each term, collapse, resistance, resilience, and transformation, to indicate status of a regime, not the underlying process or trajectory. Although it is accepted that each regime will have internal dynamics, our primary interest is in the movement of regimes between states captured by the notion of transition. Each state represents a bundle of public policies and planning strategies associated with the urban adaptation-development nexus. Together the four regime states represent a classification based on empirical conditions and a critical assessment of activities taking place within individual cities. This classification schema is similar to other efforts within urban development theory (Mossberger and Stoker 2001). As such, the readers should see each status, e.g., resilience, as a dominant paradigm of a city's risk management and development institutions rather than a quality of that management group itself. Table 1 summarizes the characteristics, causes, and potential consequences of each regime, while Table 2 illustrates each regime state with respect to actor viewpoint and object of interest as well as providing general indicators.

Risk management regimes overlap and coexist across sectors and scales. In each locale, any number or combination of regimes could be present simultaneously. For example, different climate risks, e.g., flood, drought, heat wave, or storm surge, could have different risk management regimes associated with them. In addition, each management or resource sector, e.g., transportation, energy, water supply, and public health, or even specific agency, bureau, or department might embrace varying regimes. Individual regimes will vary in their internal coherence and apparent degrees of stability but also are always being contested and remade. This creative tension connects cultural and economic values with organizational structure, interests, and policies and in turn can allow for demands of policy and management transitions to be debated and realized.

The main interest of the framework is not in mapping regime states, but in revealing the possibility of transition between states. Drawing from socio-technological systems thinking, transitions may be fast or slow, intentional or forced, proactive or reactive, planned or surprising and are often associated with resultant regime shifts and tipping points, i.e., moments of system alteration where rapid change could take place (Geels and Schot 2007). For example, Wallace and Wallace 2008, Ernstson et al. 2010, Smith and Sterling 2010, Markard et al. 2012 describe the conditions of transitions in urbanized settings and other human 
Table 2. Risk management regimes each with actor viewpoint and object of interest.

\begin{tabular}{|c|c|c|c|c|}
\hline $\begin{array}{l}\text { Actor Viewpoint } \\
\text { Object of interest }\end{array}$ & Collapse & Resistance & Resilience & Transformation \\
\hline \multicolumn{5}{|l|}{ City Planner } \\
\hline $\begin{array}{l}\text { Formal urban } \\
\text { planning regime }\end{array}$ & $\begin{array}{l}\text { Impossible to plan, no central } \\
\text { strategy (e.g., informal land } \\
\text { use or systemic corruption) }\end{array}$ & $\begin{array}{l}\text { Conservative, resistant to } \\
\text { innovation (e.g., authoritarian, } \\
\text { strong market liberal) }\end{array}$ & $\begin{array}{l}\text { Aims fixed, flexible in } \\
\text { methods, tolerates some } \\
\text { negotiation on aims (e.g., co- } \\
\text { option, patronage) }\end{array}$ & $\begin{array}{l}\text { New vision (e.g., shift from } \\
\text { market to strategic planning; } \\
\text { welfare to individual } \\
\text { responsibility) }\end{array}$ \\
\hline \multicolumn{5}{|l|}{ Infrastructure Planner } \\
\hline $\begin{array}{l}\text { Formal potable } \\
\text { water provision }\end{array}$ & $\begin{array}{l}\text { Formal provision of } \\
\text { infrastructure inadequate with } \\
\text { many inequitable, informal } \\
\text { alternatives (e.g., water } \\
\text { vendors unregulated) }\end{array}$ & $\begin{array}{l}\text { Single goal coupled with high } \\
\text { capacity to enforce preferred } \\
\text { delivery mode } \\
\text { (e.g., water vendors demonized } \\
\text { and arrested) }\end{array}$ & $\begin{array}{l}\text { Single goal coupled with } \\
\text { flexible delivery, negotiation in } \\
\text { management practice (e.g., } \\
\text { water vendors regularized and } \\
\text { accommodated) }\end{array}$ & $\begin{array}{l}\text { New vision and implementation } \\
\text { (e.g., decentralized community } \\
\text { water management system, local } \\
\text { harvesting, wells, payment, etc.) }\end{array}$ \\
\hline \multicolumn{5}{|c|}{ Disaster Risk Management Planner } \\
\hline $\begin{array}{l}\text { Formal risk } \\
\text { management } \\
\text { regime }\end{array}$ & $\begin{array}{l}\text { Inability or inaction to cater } \\
\text { for increasing disaster risk, } \\
\text { which might lead to excessive } \\
\text { disaster loss (e.g., unacceptable } \\
\text { loss, chronic or acute) }\end{array}$ & $\begin{array}{l}\text { Plans for stability in } \\
\text { underlying economic and } \\
\text { political core, social relations } \\
\text { to shield existing urban } \\
\text { systems against increasing } \\
\text { hazard trends (e.g., increasing } \\
\text { flood defenses) }\end{array}$ & $\begin{array}{l}\text { Core economic, political, and } \\
\text { social relations traded off (e.g., } \\
\text { local coast retreat) }\end{array}$ & $\begin{array}{l}\text { New vision (e.g., from hazard to } \\
\text { vulnerability or proximate to } \\
\text { root cause paradigm; risk } \\
\text { management as part of wider } \\
\text { social safety net) }\end{array}$ \\
\hline \multicolumn{5}{|l|}{ Household at risk } \\
\hline $\begin{array}{l}\text { Household } \\
\text { reproduction/ } \\
\text { economy }\end{array}$ & $\begin{array}{l}\text { Exploitive relations, stress } \\
\text { migration (e.g., sex economy, } \\
\text { homelessness, IDPs) }\end{array}$ & $\begin{array}{l}\text { Core of health and productive } \\
\text { assets protected (e.g., by } \\
\text { insurance, savings, assets, } \\
\text { external environment) }\end{array}$ & $\begin{array}{l}\text { Core of health and productive } \\
\text { assets traded off, (e.g., fewer } \\
\text { meals, change livelihood, } \\
\text { withdraw from education) }\end{array}$ & $\begin{array}{l}\text { New household form to enable } \\
\text { preferred health and productive } \\
\text { relations (e.g., shift from } \\
\text { individual to collective role, } \\
\text { economic/education migration) }\end{array}$ \\
\hline \multicolumn{5}{|l|}{ Generic indicators } \\
\hline & $\begin{array}{l}\text { Multiple coexisting, } \\
\text { contradictory goals/Unable to } \\
\text { plan/Uncontrolled loss; No } \\
\text { systems structure for strategic } \\
\text { learning }\end{array}$ & $\begin{array}{l}\text { Non-negotiable goal (methods } \\
\text { may be diverse)/ loss not } \\
\text { tolerated/ strength with a } \\
\text { break point; Single-loop } \\
\text { learning }\end{array}$ & $\begin{array}{l}\text { Goal negotiated at the } \\
\text { margins/loss at the margins } \\
\text { tolerated/flexibility to survive; } \\
\text { Double-loop learning }\end{array}$ & $\begin{array}{l}\text { Goal recognized as } \\
\text { inappropriate/strategic and } \\
\text { planned alternative/ state } \\
\text { change enables preferred } \\
\text { immediate future; Triple-loop } \\
\text { learning }\end{array}$ \\
\hline
\end{tabular}

dominated settings; Beilin et al. 2013 and Lin and Petersen 2013 focus on the mechanics of transitions and role of social networks; Bentley et al. 2014, Marin et al. 2014, Rocha et al. 2015 describe the conditions of tipping points and abrupt shifts within social and social-ecological systems. Resultant regime shifts are associated with large and persistent changes in the structure and function of a system that are often only recognizable after the fact.

Risk management regime shifts include potentially fundamental changes in wider governance structures or policy objectives. Multiple, nested systems can change form or function in a cascade of adjustments. For example, a cultural shift in the importance of wetlands in the Netherlands stimulated a wide variety of changes in legislation or regulations regarding their use and protection, and a policy shift from engineered coastal defense to a more ecologically flexible coastal and river management (Warner 2003). Resistant management systems, even manifest and defined by an individual policy leader or entrepreneur, can suppress transition (Pelling 2011). Furthermore, feedback effects can suspend or accelerate the drive for urban regime change particularly in conditions where individual self-interest conflicts or concurs with community interests (Tidball and Stedman 2013). Feedback effects can be enhanced when they are associated with increased communication and influence across institutional or geographic scales (Sage et al. 2015).
By recognizing the possibility for transition between regime states that might otherwise appear naturalized and unmovable, the framework draws attention to the valuing and redistribution of potential loss and damages over both space and time. Transitions between risk management regime types then become a central pivot point for planning pathways to sustainable and equitable development (Wilson 2013). It is during these transitions that significant progress toward sustainability can take place.

\section{A FRAMEWORK FOR ANALYZING TRANSITIONS BETWEEN RISK MANAGEMENT REGIMES}

Risk management regimes are part of the unfolding of urban development trajectories (see Pelling 2011, Pelling et al. 2012, Solecki et al. 2013, Wise et al. 2014, Garschagen and RomeroLankao 2015 as examples). Such regimes play a critical role in expressing and making evident the extent to which city actors consider large-scale development policy and practice questions such as what type of spatial planning to enact, and types of regulatory and administrative controls and incentives to use. These questions include what amount and intensity of stakeholder engagement (e.g., private sector, community organization) and change (e.g., new, publicly financed, infrastructure development) are required to support safe and equitable futures, or indeed if there is sufficient strategic capacity to face these demands. We develop an analytical framework for articulating those aspects of risk management regimes, and their 
relationship to development policy and practice that shape capacity for transitions. The framework has five key components to help guide analysis and policy work around transitions in risk management as a development concern:

- Risk management regime: the overarching orientation, goals, structure, and performance of risk management for a city.

- Development pathway: the constantly evolving relationship between social and biophysical systems mediated by policies and practices considered in relation to sustainability limits.

- Activity sphere: the total idea and material space available to the actors in a risk management regime and through which the regime is continually reproduced. The activity sphere is composed of several activity spaces.

- Activity spaces: specific components of a regime's activity sphere where social actors and structures interact to constantly reproduce potential for transition or stability in a risk management regime, for example in policies affecting land use decisions, the siting of critical infrastructure, and urban development strategies.

- Root, contextual, and proximate drivers: the interaction of actors is reflective of and mediated by a set of drivers that represent differing structural and interpersonal conditions.

The literature on regime analysis highlights interaction between economic and political structures, social institutions, and individual or organizational agency as codeterminants of innovation (Giddens 1984). Building on this tradition, our understanding of transition in risk management as a development concern draws in particular on David Harvey's (2010) work. Harvey is interested in the ways the form of different political economy regimes shapes the emergence of novelty and processes of political change. He describes the possible space for innovation and change as an activity sphere. These are then examined as entities where the interaction of popular discourse, technology, organizational forms, and routinized behavior creates sites where innovation can arise and novelty is expressed and felt. The notion of activity sphere and its constituent sites provides a usefully comprehensive view of a risk management regime that can guide analysis into the emergence, control, and expression of transition. To move from a political economy to a political ecology frame we apply Pelling et al.'s (2015) reinterpretation of Harvey's work. This identifies within the activity sphere seven so-called activity spaces, including: the individual and identity; technology (including organizational forms); livelihoods and economy; popular and political discourse; everyday behavior; environment; and cultural and legal institutions (Fig. 1).

Being able to identify situations where transitions are emergent, constrained, or accelerated within an activity sphere is important for helping to focus analytical and normative attention. This can open conversations about barriers to movement of transitional ideas, e.g., from informal but routinized behavior to formal discourse and institutions. Such analysis is also important for identifying competing transitional visions and trajectories, e.g., for greater individual or collective responsibility in risk management and any trade-offs for development gain. Elements of the decision-making processes that occur within activity spaces include goal formulation, conflict mediation, and actual policy making around different adaptation regimes. The interactions within and across activity spaces are multifaceted, shaped by different value systems and asymmetries in power and knowledge.

Fig. 1. Adaptation activity sphere within observed and future scenario limits.

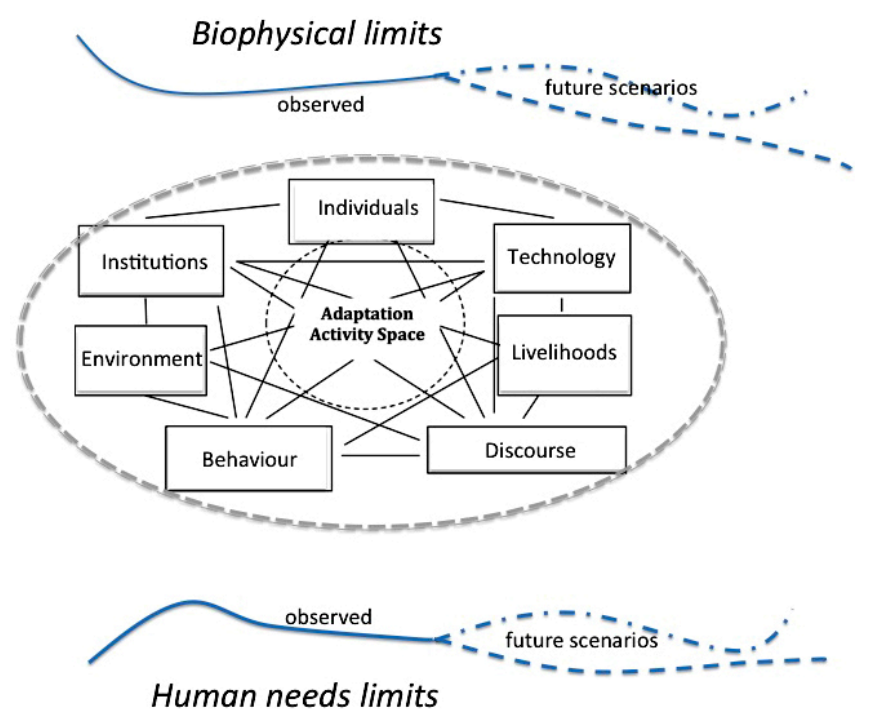

Interactions play out differently in particular sites and can involve positive and negative feedback effects that lead to either synergistic or catalytic pressure for transition, blockage of change, or backsliding over time. As an example, a technological innovation such as new flood protection technologies might dominate an activity sphere promoting resistance strategies thereby blocking a more profound transition to transformative adaptation rooted in land use or socially progressive insurance and loss sharing financial instruments. Activity spaces are scale independent and can be applied at the household, neighborhood/ community, and municipality scales and beyond. This opens scope for cross-scalar analysis of transitional capacity and pathways. It also allows asking where the burdens of costs, or benefits accrue and where innovation arises across scales and associated interest groups in the city.

The proposed framework understands development as projecting a pathway through time. At its most basic, a development pathway can be seen in relation to biophysical and social limits. Sustainable development operates between these limits, which themselves are movable as technology, culture, and biophysical processes coevolve and limits are socially renegotiated (Norgaard 1994). Risk management contributes to steering between these two limits as development paths unfold through time. Steering is an outcome of the wider urban system and the behavior of a risk management regime, as expressed in its constituent activity spaces and their interactions. This guiding within a specific risk management regime illustrates the range of flexible adaptation options open to decision makers. The direction, speed, and scope (breath) of transitions in the risk management-development relationship are open to a variety of factors including the influence by (1) the 
character of initiating conditions; these could be policy initiatives, political change, or disaster impacts, which may be combined or cascading, as well as amplified or reduced through wider social mediation, (2) the structure and function of the system of interest, and (3) the wider operating environment within which the system of interest is situated.

Here, we cannot fully specify which of these factors play an initiating role or the relative influence of each factor. Every policy transition will have qualities unique to the particular situation but also qualities that are comparable to other cases. We can acknowledge at this point that all risk management regimes as well as the transitions between them are shaped and reshaped by the interacting forces of structure and agency within the system. This fundamental interplay is well illustrated in a variety of poststructuralist approaches including those applying structuration (Pelling and Manuel-Navarette 2011), urban studies (Vale 2014), and political ecology (Sultana and Loftus 2012). Both structure and agency can reinforce existing risk management regimes. Transition is typically thought of as being dependent on a critical mass of agency realized by innovative pioneers within the system (Pelling and Manuel-Navarette 2011). Yet, the question of whether a system's structures can in and of itself cause transitions remains unclear, adding to the motivation for the conceptual research presented here.

The likelihood that stress and (or) shocks will influence the structure or existence of regimes at any one point in time is dependent on the orientation of such systems to collapse, resistance, resilience, or transformation. Stress and shocks can drive the likelihood and direction of transitions that change the character of systems, stimulate systems to self-organize into new forms, or create the conditions under which systems are destroyed (or destroy themselves) and new systems evolve and (or) are created. These transitions can include the consequences of intentional action of other systems or systems elements (e.g., through legislation, action of the market). In this sense, environmental stresses and shocks always act through social system elements, i.e., institutions, to impact broader social systems.

It is also important to recognize that transitions may only be partial; for example, when a particular governance structure or organization shifts policy behavior in a radical way, these shifts may not be carried over into other parts of the activity sphere. In these cases, changes in direction may be only temporary. The possibility also exists that once one site changes these adjustments may cause cascading change between various sites of the system, allowing for the possibility that the entire activity sphere moves closer toward transition. Components of the system strongly resistant to change (or the anticipated direction of change and its consequences) may keep the system from reaching a transition point. Following Scheffer (2009) and Scheffer et al. (2012), we hypothesize that movement between states need not be linear, that it is possible to transition by jumping states, for example a regime aiming for resilience could rapidly slip into collapse following an external shock or implosion of capacity and need not go through a state of resistance. Empirical evidence is needed to confirm this and the possibility that a system would need to occupy the intervening state, even in a highly temporary moment.
Collapse, resistance, resilience, and transformation describe the status of a risk management regime whose behavior and properties can be analyzed through the adaptation activity sphere and its component sites. No a priori normative preference for any state exists. Transition from collapse through to transformation indicates a continuum of increasing adaptation options (see Table 1). Figure 2 illustrates this with a risk management regime shown as its adaptation activity sphere functioning as a site of resistance. It is possible for this system to undergo a transition along a narrowing adaptation pathway, associated with fewer adaptation options and choices, that may lead the system to collapse. Conversely, a transition along a widening adaptation pathway may eventually project the system to a transforming regime state.

Fig. 2. Adaptation pathways and the adaptation activity sphere located within the resistance risk management regime.

Biophysical limits

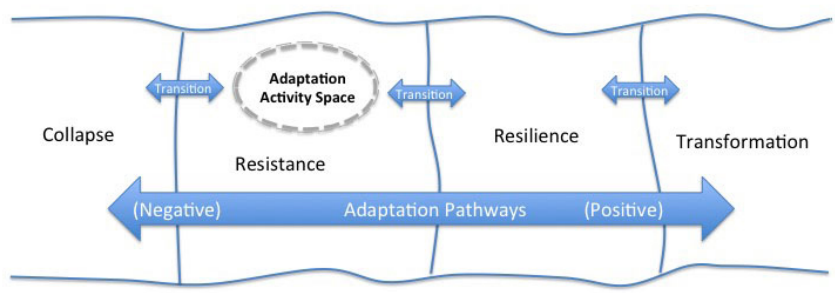

Human needs limits

Note - Time in this diagram is not left to right. Adaptation pathways can move from a lower state to higher state (i.e. left to right) or from a higher state to lower state (i.e., right to left); Time is referenced from the current to moments or eras in a future time.

Connections between the biophysical and human limits of a city's development pathway and the activity sphere of a risk management regime are influenced by proximate (e.g., local social activity), contextual (e.g., strategic policy), and root (e.g., historical, cultural norms and values) drivers (Wisner et al. 2004). Each of the drivers may interact with other drivers as well as evolve on their own. For example, contextual variables (e.g., property insurance rates) and proximate drivers such as the largescale presence of wealthy property owners who are able to take on the higher risk or poorer property owners who are unable to move will together influence whether or not transitions to potentially transformative coastline retreat discussions emerge at a particular time or place. Proximate, contextual and root drivers influence the character and conditions for action and decisionmaking processes within the activity sphere including circumstances for shifts in policy goals and objectives, number and types of participants, the articulation of power relations, and knowledge generation and learning constraints and opportunities. System level feedbacks (either positive or negative) across drivers are likely to be the connection points that result in contagions influencing the potential and trajectory of a transition.

\section{FRAMEWORK ILLUSTRATION AND VALIDATION}

We illustrate and attempt to validate elements of the framework through case examples of risk management regimes in New York 
City. For New York City, flooding from Hurricane Sandy in October 2012 was widespread, killing 43 people within the city, flooding approximately $17 \%$ of the city's land mass, causing mass evacuations, damaging tens of thousands of residences, and severely disrupting daily life in coastal communities for months (NYC SIRR 2013). The storm eventually resulted in approximately US\$20 billion of loss and damages for the City of New York. This section presents summary assessment of regime status and transition in two urban coastal residential locations on the fringe of New York City, i.e., Jamaica Bay and Raritan Bay. The aim is to show the range and depth of policy and research questions that arise from moving the adaptation debate from a focus on state, i.e., current policy conditions, to a focus on transitions; and to indicate the data requirements and policy implications of an approach that places the relationships between risk management and urban development as center stage (for fuller case study analysis, see background paper Solecki et al. 2016a; Garschagen, Pelling, Solecki, et al., unpublished manuscript). The case examples utilize data from policy review and focus groups and expert interviews with city managers and other stakeholders to define the baseline, dominant relationship between development and risk management and conditions of risk management transitions.

Risk management regimes and transitions at the urban fringe Hurricane Sandy's greatest impact was seen in the city's coastal communities. In many cases, people have not been able to return to their homes or sold their homes, and many businesses remain shuttered following the storm (Abramson et al. 2015). The examples of Jamaica Bay and Raritan Bay are illustrative of the social struggles and tensions that are opened by transitions following large scale extreme events but largely left out of formal discussions of risk management and adaptation.

\section{Development pathways}

An examination of development pathways is fundamental to understanding the process of transition underway in Jamaica Bay and Raritan Bay. ${ }^{[5]}$

\section{Biophysical limits: storm surge, flooding, and sea level rise}

As coastal sites, Jamaica Bay and Raritan Bay and immediately surrounding land areas have experienced numerous storm surge events in the past; however, no significant flooding events had occurred in the region for over 50 years. On Staten Island, the most at-risk area is a low-lying coastal region stretching between the Raritan Bay and the elevated interior of the island; while for Jamaica Bay a much wider area of low elevation is present, extending inland from the water's edge for approximately $10 \mathrm{~km}$. Given this coastline's exposure to the Atlantic Ocean, the bays experience heightened storm surge and wave action risk. The low elevation gradients and wide watershed areas in the waterfront Jamaica Bay communities also have resulted in nuisance flooding during extremely heavy downpours, especially when coinciding with unusually high tides, e.g., lunar tides (Fitzpatrick 2014, http://blog.ucsusa.org/melanie-fitzpatrick/sea-level-rise-in-jamaicabay-new-york-688).

The advent of climate change and associated accelerated sea level rise and potential increased frequency and intensity of storms has forced the coastal communities and the several hundred thousand residents along the bays to reconsider their short- and long-term hazard risk management strategies. The New York Metropolitan Region experienced significant sea level rise during the 20th century. Sea level rise averaged $3.0 \mathrm{~cm}$ (1.2 inches) per decade (total of $33.5 \mathrm{~cm}$ ), nearly twice the observed global rate over a similar time period. The midrange projections for sea level this century is expected to rise 28 to $53 \mathrm{~cm}$ by the 2050s, 46 to $99 \mathrm{~cm}$ by the $2080 \mathrm{~s}$, and, for the high estimate ( 90 th percentile), $191 \mathrm{~cm}$ by 2100 (Rosenzweig and Solecki 2015; see Fig. 3).

Fig. 3. Future 1\% flood extent with projected sea level rise (source: Rosenzweig and Solecki 2015).

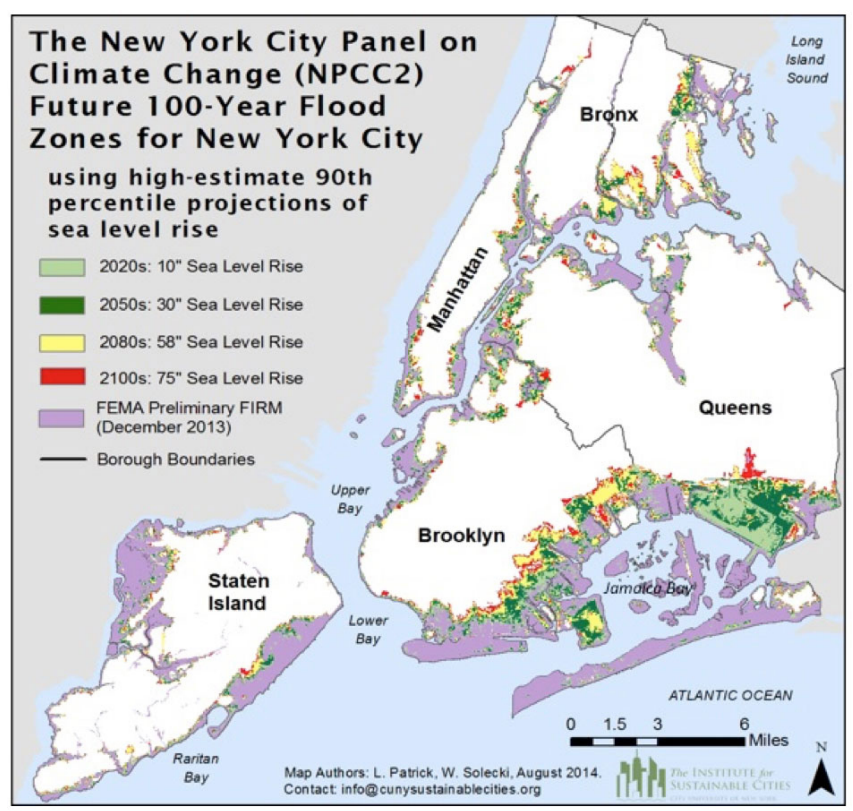

2. Human need limits: marginality, vulnerability, and externalities

The bay area communities' adaptive capacity can be best described as limited because of a variety of socioeconomic and infrastructure constraints. A significant proportion of the area communities are low to moderate income, minority, i.e. nonwhite, and lack English as their primary language (U.S. Census Bureau 2016, Ramasubramanian et al. 2016). Numerous public housing facilities, most of which are high multistory structures, or other government-sponsored institutional housing including for the elderly and mentally handicapped, especially around Jamaica Bay, are present (NYC SIRR 2013). Another sizable component of the residential properties comprises former seasonal housing, e.g., summer bungalows, that have been converted to all year use (Waldman and Solecki 2016, unpublished manuscript). As a result, their construction is rather simple and highly vulnerable structurally to wave action and flooding (Sanderson et al. 2016). Given that the communities on both bays are quite distant from central business districts in the region, have limited access to commuter rail and other transit infrastructure, and are the location for numerous environmentally detrimental facilities and sites (include waste dumps, sewerage treatment plants, and John F. Kennedy airport), these areas are typically considered as 
economically and politically marginal in New York City. Even so, these communities have long and established traditions of social organization around issues of local quality of life concerns (Allred et al. 2016). The urban neighborhoods around Jamaica Bay and Raritan Bay are projected to age and further racially and ethnically diversify in the near future.

As of 2017, the repercussions of Hurricane Sandy are still being felt in the neighborhoods along the two bays. Although a significant amount of rebuilding of individual properties has taken place, the overall trajectory of future development is still not clear. Overall, the communities around the bays are still largely in a highly dynamic postdisaster state. The residential and commercial dislocation, government buyout programs of severely damaged or destroyed properties, and debates regarding postSandy flood protection and development projects have become major concerns for the communities. The loss of community, prospect of widespread property transfer and potential gentrification, large scale flood control infrastructure projects, increased financial burden on property owners for flood insurance, and uncertainty regarding future risk have placed residents and their everyday lives under significant stress (Crean 2013, 2015, Gruebner et al. 2015, Lowe et al. 2015). In some cases, this stress has been utilized to promote increased civic engagement, social activism, and community building, but in other neighborhoods the stress has resulted in social divisions and tensions, loss of neighborhood cohesion, and reduced adaptive capacity (Allred et al. 2016). These circumstances present potential openings for transition to collapse or transformation. Stasis even with flexibility seems unlikely.

Root, contextual, and proximate drivers

In the framework, we posit that root, contextual, and proximate drivers operating within the activity sphere influence the structure and character of local adaptation efforts. In the case of Jamaica Bay and Raritan Bay, both areas have a long history of human use that is relevant to fully understand the current debates about flood risk management.

With respect to root drivers, early initial European colonial settlements within the two bays were centered on fishing and oyster harvesting (MacKenzie 1992). By the late 20th century, Jamaica Bay had been severely altered by major infrastructure construction, e.g., new highways, and a major international airport: Kennedy International Airport, tracks of multifamily and single-family homes, and commercial and business centers. Although almost all the pre-European contact wetlands were destroyed, remnant and still ecologically important parcels were incorporated into a wildlife management area and open space. The current juxtaposition of a necklace of waste sites, sewerage treatment facilities, strip malls, and one of the busiest international airports with thousands of hectares of protected marsh islands and continentally important waterfowl habitat is quite striking (Miller 2000; Waldman and Solecki 2016, unpublished manuscript). The last quarter of the 20th century brought increasing interest in urban wildlife protection and urban ecosystem restoration. Their perceived value for water quality protection and flood control has been especially significant in the post-Sandy period. These changing attitudes have dramatically increased the ambition of environmentally focused stakeholders to protect and enhance the bays' ecology and value for recreation and habitat, and storm surge mitigation.
Several sets of contextual drivers are particularly relevant for understanding the risk management regime in the two bays. Three examples of contextual drivers partially emerge from the longer term growing interest among New Yorkers in living and recreating along the city's waterfront edge. Residents in the two sites have had increased attention in the following: (1) locally driven postSandy participatory planning and budgeting processes, (2) the complex and often contradictory public and private flood prone property management of Jamaica Bay and Raritan Bay waterfront, and (3) enhanced civil society participation overall.

The right of private property, in the U.S., is paramount but all properties have to be managed within the context of limiting negative externalities and within local zoning and construction requirements, e.g., minimal parcel size, height limits, and easements. Private property rights constrain the opportunity for bay-wide development and regional land use planning efforts. Publicly owned lands and public infrastructure and other parcels near the bays are separately managed by the multitude of municipal, regional, county, state, and federal agencies. Numerous jurisdictional and mandate conflicts exist that have further hampered regional planning and integrated management efforts. For example, at least a dozen different local, state, and federal agencies have control over different components of Jamaica Bay's open space and waterways. The U.S. Army Corps of Engineers is a critical stakeholder because they have U.S. Congress-mandated control of all navigable waters and associated flood control structures.

The most significant proximate driver of the risk management regime is the ongoing aftermath of Hurricane Sandy and the lens through which the Bloomberg administration (NYC Mayor from 2002 to the end of 2013) and current de Blasio administration (NYC Mayor starting on 1 January 2014) see this disaster. Bloomberg initiated an aggressive set of climate adaptation and mitigation actions in the 2000s as part of his innovative "PlaNYC" effort. After Sandy, the administration authored the Special Initiative on Rebuilding and Resiliency Report (2013) that focused on several hundred strategies to promote flood protection and long-term resilience. The meta-narrative of the report was a flexible, distributed resiliency planning effort that promotes resilient redevelopment of the coast without retreat.

The new administration of Mayor Bill de Blasio in April 2015 released its version of a comprehensive sustainability plan for the City, entitled "OneNYC" as opposed to PlaNYC (NYC 2015). This built upon Bloomberg's approach but the overall development trajectory was different. The plan is designed to highlight the connections between sustainability, justice, and equity. More specifically, for adaptation, the OneNYC effort is largely focused on making the city more resilient and eliminating disaster-related long-term displacement, i.e., more than 1 year, reducing social vulnerability of neighborhoods, and decreasing the average annual economic losses from climate-related events, with strategies targeted at neighborhoods, buildings, infrastructure, and coastal defenses. In full, the de Blasio administration is building on the ambitious history of climate action in the city while broadening its approach and appeal to a larger set of New Yorkers. Previous efforts had been critiqued as too elitist, overly focused on the wealthiest borough (Manhattan), and too technocratic and top-down, with limited opportunities for public involvement (Rosan 2011). The current efforts, which 
attempt to combine a climate change agenda with equity and justice concerns, and openness to broader civic society engagement, could provide a foundation for more transformative climate action.

The lingering impacts of Hurricane Sandy and planned rebuilding have fostered groups of losers and winners. The largest group of disadvantaged individuals is those dislocated from their homes and unable to return. Other contestation is emerging over which properties should be classified within the $1 \%$ flood zone, i.e., areas that have $1 \%$ probability of being flooded in any year, and what kind of associated insurance burden do those property owners need to bear. The U.S. Federal Emergency Management Agency (FEMA) released a revised 1\% flood map in 2013. The revision presented a wide expansion of the $1 \%$ flood zone, especially in the Jamaica Bay area, and placed thousands of structures not previously located in a high flood hazard zone in such a zone. The City of New York and other municipalities in the region have legally contested the revisions as too expansive. The resolution of this issue and many other similar high profile responses to Hurricane Sandy, e.g., whether or not to build a storm surge barrier at the mouth of Jamaica Bay, what should be done with the damaged homes and properties that the State of New York or the City of New York have bought out, will contribute to conditions for potential risk management regime change.

\section{Adaptation activity sphere and transition activity space}

Physical limits, human needs limits, and the set of drivers provide the background conditions under which the risk management decision making takes place. The fusion and integration of these components takes place within the adaptation activity sphere (defined here as a social-ecological system space composed of seven elements: individuals, technology, livelihoods, discourse, behavior, environment, and institutions). It is the simultaneous interaction of these seven elements with positive or negative feedbacks and scalar-influenced, i.e., household, community, region, etc., connections that define the conditions for risk management and the direction of potential transition of the current regime to another regime. The speed of the connections (e.g., how fast or slow, continuous or discontinuous), direction (e.g., which connections dominate, and which way is the direction), and breadth (e.g., how much connectivity takes place, character of the connections) are critical descriptors of how the system is functioning and on which pathway it might be moving.

Within the communities along the Jamaica Bay and Raritan Bay, this understanding has significant implications for interpreting the behavior of residents and businesses that illustrate the underlying tensions between livelihoods, development, and risk management. Hundreds of homes in the Hurricane Sandy flooded areas of Staten Island have been bought by the State of New York and converted to open space. An implicit assumption seems to be emerging that these homes and parts of neighborhoods, such as Oakwood Beach, New Dorp Beach, and Midland Beach, should not have been initially developed (Tollefson 2013, Barone 2014, Jacob 2015). They were high-risk locations in a relatively remote part of New York City. Furthermore, the local topography is such that once these structures are razed much of the remaining nearshore zone given its high relief and higher elevation will be relatively safe from future flooding, except in the event of a catastrophic hurricane (a strong category 3 storm or higher on the Saffir-Simpson scale) heretofore not historically observed in the region (Hurricane Sandy made landfall just after it technically lost hurricane wind speed status: < $75 \mathrm{mph}$; Category 1 Hurricane).

For coastal Staten Island neighborhoods, a period of contestation, introspection, and resignation occurred in the months following Hurricane Sandy. Individual homeowners struggled with their decisions about how to respond to the damage: rebuild, relocate, or seek a buyout (Solecki 2016). Neighbors argued amongst themselves, and communities were split apart (Binder et al. 2015, Binder and Greer 2016, Dietrich 2016). But, what has emerged now four years on is a de facto policy of retreat and, as is, represents a transition in the risk management regime for this area from an agenda of resistance to transformation. This is significant but why was it possible? The assessment of future flood risk was compelling, the level of scientific uncertainty was relatively low, the options for transformative adaptation were clear, and the resources were available to carry out the actions. Set within the risk management regime framework, the physical limits and human needs limits were significant and constraining, the drivers for change were powerful, and eventually the inertia to transition faded within the adaptation activity sphere and opportunities and benefits of regime change became more evident and powerful.

The case of Jamaica Bay is more complex. The region is intensely integrated into the urban fabric of the city; critical infrastructure line and crisscross the area, significant numbers of at-risk residents are present, and interest in the amenity and ecosystem resource value of Jamaica Bay and environs have increased dramatically in recent years. In addition, the topography of the Bay and its watershed is relatively flat with low elevation. Sea level rise and increased high precipitation events will significantly expand the number of residential and commercial properties and streets at risk to acute and chronic flooding. A process of retreat, like that emerging on the Raritan Bay shore, is much more difficult to initiate. The Bay is too materially and symbolically significant and retreat is socially, economically, and politically nonviable (Murphy 2015). Hurricane Sandy briefly pushed the issue of transformative adaptation on the Bay into a high profile position in the public and policy discourse but it is has steadily receded into the background as the years have passed. Using the transition framework, it is clear that physical limits and human needs limits as well as the drivers are powerful potential motives for shaping adaptation regimes. Even so, the structure and operation of elements within the adaptation activity sphere in the Jamaica Bay case has pressed back the likelihood of transition and has strengthened the current regime. The benefits and opportunities coming from maintaining the status quo have been well articulated and asserted with neighborhood and municipal agreement (NYC SIRR 2013, NYC Department of Planning 2016).

That said, the decision-making processes in the Jamaica Bay region about which risk management regime to pursue in the future and whether a transition is possible or likely is highly contested. Varying local and regional interest groups, including specific neighborhood groups, and local chapters of environmental NGO's, elected representatives, infrastructure agencies, continue to vie for their positions and the rhetorical and 
policy high ground (Allred et al. 2016). A hybrid regime has emerged that emphasizes both resistance and resilience in the Bay's residences, businesses, and infrastructure. Storm surge barriers around critical infrastructure facilities are being constructed, the runways of Kennedy Airport have been raised, while at the same time the New York - New Jersey Port Authority, which manages the airport, recognizes that the airport might be closed a day or two more per year in the future because of increased flooding and the need to manage for increased flooding risk (McLaughlin et al. 2011, Port Authority 2015). The City of New York is actively working on new regulations to provide insurance rate benefits to those property owners who institute flood resilience measures. The properties flooded and damaged by Hurricane Sandy that the City is buying along the Bay (not the State of New York, as is the case on Raritan Bay) will not be turned into open space but are being held for future redevelopment. The assumption is that future building will be resilient to flood storm surge, but the question remains as to who will be the residents of this new development.

An analysis of risk management transition also highlights issues of social and environmental equity in current debates for resistance and resilience within Jamaica Bay. Who will benefit from these flood protection measures and who will be disadvantaged are key questions. Progressive social activists argue that low and moderate income residents will be closed out of their neighborhoods as rising insurance rates, relocation of government sponsored housing, and developers seeking high amenity sites for up-market residents take hold (Kensinger 2016, Robbins 2016). Environmentalists are concerned that new barriers and flood control structures will further degrade the fragile, remnant wetland ecology (Schuerman 2015). Each neighborhood is arguing that it needs to be protected from future flood and warily evaluates whether other neighborhoods are getting more attention than theirs. Just as Jamaica Bay is being drawn together by new regional planning efforts, it seems to be also further split apart as the demands of climate adaptation shift from planning to practice. The neighborhoods are stridently committed to sustained settlement even as an increase in chronic flooding already is present. The key issue remains as to whether more intense physical limits illustrated by heightened rates of sea level rise and an increased likelihood of catastrophic flooding will force these communities and their stakeholders to revisit these issues and the risk management regime of the Bay.

\section{CONCLUSIONS}

The conceptual framework presented here attempts to provide an analytical lens to understand the factors associated with the development of different risk management regimes and the transitions between them. The framework is illustrated in a large urban coastal setting, but the approach attempts to be more widely applicable. The approach simultaneously requires an indepth empirical understanding of the conditions, modi operandi, and goals of current adaptation and the associated activity sphere, as well as the current and future biosphere and human needs and limits at each site. The framework aims to bridge urban adaptation and development perspectives, and allows to reconcile the normative vision spaces of both domains, which otherwise remain too often artificially separated in current risk management and adaptation debates, and their scientific analysis.
The trajectory or pathway of systems transitions is illustrative of shifting adaptation policy from a focus on defensiveness and stability-seeking to a narrative of opportunity and change. Given direction and impetus by external and internal pressures as well as historical momentum and friction with surrounding pathways, transitions arise from the connection of the past extreme events legacies, contemporary development visions, imagined urban and climate futures, and decision-making structures and actions. Transitions along adaptation pathways mean that trade-offs have to be negotiated. These trade-offs have different distributional (environmental, economic, equity) effects over space, scale, society, and time.

Deeply embedded in this approach is a set of justice questions, with political, social, and economic ramifications, regarding how ongoing and future risk management and coupled development regimes might be structured in response to the dynamic level of climate risk and assertions regarding use, occupancy, and habitation of at-risk coastal sites, just as those investigated here. Risk management regime transitions will involve debate and struggle, resulting in winners and losers. Fracture lines throughout the communities of Jamaica Bay already seem to be forming, pitting the vulnerable versus the resilient, the poor versus the wealthier, and nearshore residents versus more distant shore residents. The question of how the loss and damages of future climate change will be distributed and who will bear the costs are fundamental to tensions within these communities. The justice implications of these inequities are still emerging and contested. It is through the interplay of biophysical limits, human needs, and risk management regimes that understanding the differences among the various factions involved in the climate action debate within these sites can be realized.

${ }^{[1]}$ The paper is an output of a Belmont Forum funded project, Transformation and Resilience on Urban Coasts working in Kolkata, Lagos, London, and Tokyo as well as New York City. For additional empirical and methodological detail please consult the project website at http://www.bel-truc.org/

${ }^{[2]}$ A more historical analysis would be complementary, and part of future work to further refine strategies for validating the framework.

[3] The same movement could be viewed differently by varying stakeholders, e.g., a shift to local empowerment could look like collapse to an existing centralized regime and as transformation locally.

[4] This key conceptual differentiation between protection, accommodation, and withdrawal (retreat) is used in the IPCC, Working Group II, AR5 (IPCC 2014).

${ }^{[5]}$ Because of space limitations we do not include discussion of the other cases. This information can be found in the following background paper Solecki et al. $2016 b$ on the TRUC project website at http://www.bel-truc.org/

Responses to this article can be read online at: http://www.ecologyandsociety.org/issues/responses. $\mathrm{php} / 9102$ 


\section{Acknowledgments:}

Funding for the project comes from the U.S. National Science Foundation G8MUREFU3FP-2201-075 via the Belmont Forum. Special thanks to Michael Dorsch and Erin Friedman, City University of New York, Graduate Center for research and editorial assistance.

\section{LITERATURE CITED}

Abramson, D., D. Van Alst, A. Merdjanoff, R. Piltch-Loeb, J. Beedasy, P. Findley, L. Peek, M. Mordy, S. Morose, K. Ocasio, Y. Soo Park, J. Sury, and J. Tobin-Gurley. 2015. The Hurricane Sandy place report: evacuation decisions, housing issues and sense of community. The Sandy Child and Family Health Study. Rutgers University School of Social Work, New York University College of Global Public Health, Columbia University National Center for Disaster Preparedness, Colorado State University Center for Disaster and Risk Analysis, Boulder, Colorado, USA. [online] URL: https://hazdoc.colorado.edu/handle/10590/5781

Adger, W. N., T. P. Hughes, C. Folke, S. R. Carpenter, and J. Rockström. 2005. Social-ecological resilience to coastal disasters. Science 309:1036-1039. http://dx.doi.org/10.1126/science.1112122

Allred, S., B. DuBois, K. Bunting-Howarth, K. Tidall, and W. D. Solecki. 2016. Social-ecological system transformation in Jamaica Bay. Pages 43-62 in E. W. Sanderson, W. D. Solecki, J. R. Waldman, and A. S. Parris, editors. Prospects for resilience: insights from New York City's Jamaica Bay. Island Press, Washington, D.C., USA.

Bahadur, A., and T. Tanner. 2014. Transformational resilience thinking: putting people, power and politics at the heart of urban climate resilience. Environment \& Urbanization 26(1):200-214. http://dx.doi.org/10.1177/0956247814522154

Barone, V. 2014. Gov. Cuomo visits Staten Island to mark second anniversary of Hurricane Sandy. Staten Island Advance, 30 October. [online] URL: http://www.silive.com/eastshore/index. $\underline{\text { ssf/2014/10/govenor andrew cuomo visits oa.html }}$

Beilin, R., N. T. Richelt, B. J. King, A. Long, and S. Cam. 2013. Transition landscapes and social networks: examining on-ground community resilience and its implications for policy settings in multiscalar systems. Ecology and Society 18(2):30. http://dx.doi. org/10.5751/es-05360-180230

Bentley, R. A., E. J. Maddison, P. H. Ranner, J. Bissell, C. C. S. Caiado, P. Bhatanacharoen, T. Clark, M. Botha, F. Akinbami, M. Hollow, R. Michie, B. Huntley, S. E. Curtis, and P. Garnett. 2014. Social tipping points and Earth system dynamics. Frontiers in Environmental Science 2:35. http://dx.doi.org/10.3389/ $\underline{\text { fenvs.2014.00035 }}$

Binder, C. R., J. Hinkel, P. W. G Bots, and C. Pahl-Wostl. 2013. Comparison of frameworks for analyzing social-ecological systems. Ecology and Society 18(4):26. http://dx.doi.org/10.5751/ es-05551-180426

Binder, S. B., C. K. Baker, and J. P. Barile. 2015. Rebuild or relocate? Resilience and postdisaster decision-making after Hurricane Sandy. American Journal of Community Psychology 56:180-196. http://dx.doi.org/10.1007/s10464-015-9727-x
Binder, S. B., and A. Greer. 2016. The devil is in the details: home buyout policy, practice, and experience after Hurricane Sandy. Politics and Governance. 4:97-106. http://dx.doi.org/10.17645/ pag.v4i4.738

Brown, K., S. O’Neill, and C. Fabricius. 2013. Social science understandings of transformation. Pages 100-106 in World social science report 2013: changing global environments. International Social Science Council, UNESCO Publishing, Paris, France. http://dx.doi.org/10.1787/9789264203419-13-en

Cote, M., and A. J. Nightingale. 2012. Resilience thinking meets social theory: situating social change in socio-ecological systems (SES) research. Progress in Human Geography 36(4):475-489. http://dx.doi.org/10.1177/0309132511425708

Crean, S. 2013. Are the city's most storm-vulnerable communities being heard? Gotham Gazette, 21 October. [online] URL: http:// www.gothamgazette.com/index.php/environment/4660-special-reportare-the-citys-most-vulnerable-communities-being-heard-

Crean, S. 2015. Resiliency spotlight: Staten Island, awaiting next storm, balances long-term planning, short-term needs. Adapt NY, 16 April. [online] URL: http://www.adaptny.org/2015/04/16/ resiliency-spotlight-staten-island-awaiting-next-storm-balances-longterm-planning-short-term-needs/

Dietrich A. 2016. Sandy on Staten Island: culture, barriers to recovery, and the question of resilience. Natural Hazards Observer XL:5. [online] URL: https://hazards.colorado.edu/article/sandyon-staten-island-culture-barriers-to-recovery-and-the-question-ofresilience

Douglas, P. M. J., M. Pagani, M. A. Canuto, M. Brenner, D. A. Hodell, T. I. Eglinton, and J. H. Curtis. 2015. Drought, agricultural adaptation, and sociopolitical collapse in the Maya Lowlands. Proceedings of the National Academy of Sciences 112 (18):5607-5612. http://dx.doi.org/10.1073/pnas.1419133112

Ernstson, H., S. E. van der Leeuw, C. L. Redman, D. J. Meffert, G. Davis, C. Alfsen, and T. Elmqvist. 2010. Urban transitions: on urban resilience and human-dominated ecosystems. Ambio 39 (8):531-545. http://dx.doi.org/10.1007/s13280-010-0081-9

Ferguson, B. C., R. R. Brown, and A. Deletic. 2013. Diagnosing transformative change in urban water systems: theories and frameworks. Global Environmental Change 23(1):264-280. http:// dx.doi.org/10.1016/j.gloenvcha.2012.07.008

Folke, C., S. R. Carpenter, B. H. Walker, M. Scheffer, T. Chapin, and J. Rockstrom. 2010. Resilience thinking: integrating resilience, adaptability and transformability. Ecology and Society 15(4):20. http://dx.doi.org/10.5751/es-03610-150420

Garschagen, M. 2013. Resilience and organisational institutionalism from a cross-cultural perspective: an exploration based on urban climate change adaptation in Vietnam. Natural Hazards 67 (1):25-46. http://dx.doi.org/10.1007/s11069-011-9753-4

Garschagen, M., and P. Romero-Lankao. 2015. Exploring the relationships between urbanization trends and climate change vulnerability. Climatic Change 133(1):37-52. http://dx.doi. org/10.1007/s10584-013-0812-6

Geels, F. W., and J. Schot. 2007. Typology of sociotechnical transition pathways. Research Policy 36:399-417 http://dx.doi. org/10.1016/j.respol.2007.01.003 
Giddens, A. 1984. The constitution of society: outline of the theory of structuration. University of California Press, Berkeley, California, USA.

Gruebner, O., S. R. Lowe, L. Sampson, and S. Galea. 2015. The geography of post-disaster mental health: spatial patterning of psychological vulnerability and resilience factors in New York City after Hurricane Sandy. International Journal of Health Geographics 14(16). http://dx.doi.org/10.1186/s12942-015-0008-6

Handmer, J. W., and S. R. Dovers. 1996. A typology of resilience: rethinking institutions for sustainable development. Organization and Environment 9(4):482-511. http://dx.doi.org/10.1177/108602$\underline{669600900403}$

Harvey, D. 2010. The enigma of capital: and the crises of capitalism. Oxford University Press, Oxford, UK.

Hodbod, J., and W. N. Adger. 2014. Integrating social-ecological dynamics and resilience into energy systems research. Energy Research \& Social Science 1:226-231. http://dx.doi.org/10.1016/j. erss.2014.03.001

Holling, C. S. 1973. Resilience and stability of ecological systems. Annual Review of Ecology and Systematics 4:1-23. http://dx.doi. org/10.1146/annurev.es.04.110173.000245

Holling, C. S., L. H. Gunderson, and G. D. Peterson. 2002. Sustainability and panarchies. Pages 63-102 in L. H. Gunderson, and C. S. Holling, editors. Panarchy: understanding transformations in human and natural systems. Island, Washington, D.C., USA.

Hordijk, M., L. M. Sara, and C. Sutherland. 2014. Resilience, transition or transformation? A comparative analysis of changing water governance systems in four southern cities. Environment \& Urbanization 26(1):130-146. http://dx.doi.org/10.1177/0956247813519044

Intergovernmental Panel on Climate Change (IPCC). 2014. Climate change 2014: impacts, adaptation, and vulnerability. Part A: Global and Sectoral Aspects. Contribution of Working Group II to the Fifth Assessment Report of the Intergovernmental Panel on Climate Change. C. B. Field, V. R. Barros, D. J. Dokken, K. J. Mach, M. D. Mastrandrea, T. E. Biliar, M. Chatterjee, K. L. Ebi, Y. O. Estrada, R. C. Genova, B. Girma, E. S. Kissel, A. N. Levy, S. MacCracken, P. R. Mastrandrea, and L. L. White, editors. Cambridge University Press, Cambridge, UK.

Jacob, K. H. 2015. Sea level rise, storm risk, denial, and the future of coastal cities. Bulletin of the Atomic Scientists 71(5):40-50. http://dx.doi.org/10.1177/0096340215599777

Kensinger, N. 2016. Development threatens the future of a Far Rockaway waterway. Curbed, 11 August. [online] URL: http://ny. curbed.com/2016/8/11/12425222/bridge-creek-far-rockaways-nyc

Lin, B. B., and B. Petersen. 2013. Resilience, regime shifts, and guided transition under climate change: examining the practical difficulties of managing continually changing systems. Ecology and Society 18(1):28. http://dx.doi.org/10.5751/es-05128-180128

Logan, J. R., and H. L. Molotch. 1987. Urban fortunes: the political economy of space. University of California Press, Berkeley, California, USA.
Lowe, S. R., L. Sampson, O. Gruebner, and S. Galea. 2015. Psychological resilience after Hurricane Sandy: the influence of individual-and community-level factors on mental health after a large-scale natural disaster. PLOS ONE 10(5):e0125761. http:// dx.doi.org/10.1371/journal.pone.0125761

MacKenzie, C. L. Jr. 1992. The fisheries of Raritan Bay. Rutgers University Press, New Brunswick, New Jersey, USA.

Marin, A., S. Gelcich, and J. C. Castilla. 2014. Ecosystem services and abrupt transformations in a coastal wetland social-ecological system: Tubul-Raqui after the 2010 earthquake in Chile. Ecology and Society 19(1):22. http://dx.doi.org/10.5751/ES-05633-190122

Markard, J., R. Raven, and B. Truffer. 2012. Sustainability transitions: an emerging field of research and its prospects. Research Policy 41:955-967. http://dx.doi.org/10.1016/j.respol.2012.02.013

Marshall, N. A., S. E. Park, W. N. Adger, K. Brown, and S. M. Howden. 2012. Transformational capacity and the influence of place and identity. Environmental Research Letters 7(3):1-9. http:// dx.doi.org/10.1088/1748-9326/7/3/034022

May, P. J., and A. E. Jochim. 2013. Policy regime perspectives: policies, politics, and governing. Policy Studies Journal 41 (3):426-452. http://dx.doi.org/10.1111/psj.12024

McApline, C. A., L. M. Seabrook, J. G. Ryan, B. J. Feeney, W. J. Ripple, A. E. Ehrlich, and P. R. Elrlich. 2015. Transformational change: creating a safe operating space for humanity. Ecology and Society 20(1):56. http://dx.doi.org/10.5751/ES-07181-200156

McLaughlin, B. J., S. D. Murrell, and S. DesRoches. 2011. Anticipating climate change. Civil Engineering 81(4):50-55. http:// dx.doi.org/10.1061/ciegag.0000348

Miller, B. 2000. Fat of the land: garbage of New York, the last two hundred years. Basic Books, New York, New York, USA.

Mossberger, K., and G. Stoker. 2001. The evolution of urban regime theory: the challenge of conceptualization. Urban Affairs Review 36(6):810-835. http://dx.doi.org/10.1177/10780870122185109

Murphy, J. 2015. 3 Years after Sandy, is New York prepared for the next great storm? The Nation, 14 October. [online] URL: https://www.thenation.com/article/3-years-after-hurricane-sandyis-new-york-prepared-for-the-next-great-storm/

New York City, Department of City Planning. 2016. Resilient neighborhoods: Old Howard Beach, Hamilton Beach and Broad Channel. Department of City Planning, New York, New York, USA. [online] URL: http://www1.nyc.gov/site/planning/plans/ resilient-neighborhoods/old-howard-beach-hamilton-beach-broadchannel.page

New York City, Office of the Mayor. 2015. One New York: the plan for a strong and just city. Office of the Mayor, New York, New York, USA. [online] URL: http://www.nyc.gov/html/ onenyc/downloads/pdf/publications/OneNYC.pdf

New York City, Special Initiative for Rebuilding and Resiliency (NYC SIRR). 2013. A stronger more resilient New York: special initiative on rebuilding and resiliency. SIRR, New York, New York, USA. [online] URL: http://s-media.nyc.gov/agencies/sirr/ SIRR singles Lo res.pdf 
Norgaard, R. 1994. Development betrayed: the end of progress and a coevolutionary revisioning of the future. Routledge, London, UK.

O'Brien, K. 2012. Global environmental change II: from adaptation to deliberate transformation. Progress in Human Geography 36(5):667-676. http://dx.doi.org/10.1177/0309132511425767

Olsson, P., V. Galaz, and W. J. Boonstra. 2014. Sustainability transformations: a resilience perspective. Ecology and Society 19 (4):1. http://dx.doi.org/10.5751/es-06799-190401

Pahl-Wostl, C. 2007. Transitions towards adaptive management of water facing climate and global change. Water Resource Management 21(1):49-62. http://dx.doi.org/10.1007/s11269-006-9040-4

Pelling, M. 2003. The vulnerability of cities: social resilience and natural disaster. Earthscan, London, UK.

Pelling, M. 2011. Adaptation to climate change: from resilience to transformation. Routledge, New York, New York, USA.

Pelling, M., and S. Blackburn, editors. 2013. Megacities and the coast: risk, resilience and transformation. Routledge, New York, New York, USA.

Pelling, M., and D. Manuel-Navarrete. 2011. From resilience to transformation: the adaptive cycle in two Mexican urban centers. Ecology and Society 16(2):11. http://dx.doi.org/10.5751/ es-04038-160211

Pelling, M., D. Manuel-Navarrete, and M. Redclift, editors. 2012. Climate change and the crisis of capitalism: a chance to reclaim self, society and nature. Routledge, New York, New York, USA.

Pelling, M., K. O'Brien, and D. Matyas. 2015. Adaptation and transformation. Climatic Change 33(1):113-127. http://dx.doi. org/10.1007/s10584-014-1303-0

Polechová, J., and N. H. Barton. 2015. Limits to adaptation along environmental gradients. Proceedings of the National Academy of Sciences 112(20):6401-6406. http://dx.doi.org/10.1073/pnas.1421515112

Port Authority of New York and New Jersey, Engineering Department. 2015. Design guidelines, climate resilience. Port Authority of New York and New Jersey, New York, New York, USA. [online] URL: https://www.panynj.gov/business-opportunities/ pdf/discipline-guidelines/climate-resilience.pdf

Ramasubramanian, L., M. Menser, E. Reiser, L. Feder, R. Forrester, R. Leichenko, S. Allred, G. Ferenz, M. Brezin, J. Bolstad, W. Meyer, and K. Tidball. 2016. Strategies for community resilience practice for the Jamaica Bay Watershed. Pages 241-252 in E. W. Sanderson, W. D. Solecki, J. R. Waldman, and A. S. Parris, editors. Prospects for resilience: insights from New York City's Jamaica Bay. Island Press, Washington, D.C., USA.

Robbins, C. 2016. Gentrified aquarium: De Blasio's streetcar and the tale of two waterfronts. Village Voice, 13 September. [online] URL: http://www.villagevoice.com/news/gentrified-aquariumde-blasios-streetcar-and-the-tale-of-two-waterfronts-9100323

Rocha, J. C., G. D. Peterson, and R. Biggs. 2015. Regime shifts in the Anthropocene: drivers, risks, and resilience. PLOS ONE 10 (8):e0134639. http://dx.doi.org/10.1371/journal.pone.0134639
Rosan C. D. 2011. Can PlaNYC make New York City "greener and greater" for everyone?: sustainability planning and the promise of environmental justice. Local Environment 17 (9):959-976. http://dx.doi.org/10.1080/13549839.2011.627322

Rosenzweig, C., and W. Solecki, editors. 2015. Building the knowledge base for climate resiliency: New York City panel on climate change 2015 report. New York Academy of Sciences, New York, New York, USA.

Rotberg, R. I. 2011. Failed states, collapsed states, and weak states: causes and indicators. Wilson Center, Washington, D.C., USA. [online] URL: https://www.wilsoncenter.org/publication/failed$\underline{\text { states-collapsed-states-and-weak-states-causes-and-indicators }}$

Sage, D., P. Fussey, and A. Dainty. 2015. Securing and scaling resilient futures: neoliberalization, infrastructure, and topologies of power. Environment and Planning D: Society and Space 33:494-511. http://dx.doi.org/10.1068/d14154p

Sanderson, E., W. Solecki, J. Waldman, and A. Parris, editors. 2016. Prospects for resilience: insights from New York City's Jamaica Bay. Island Press, Washington, D.C., USA.

Scheffer, M. 2009. Critical transitions in nature and society. Princeton University Press, Princeton, New Jersey, USA.

Scheffer, M., S. R. Carpenter, T. M. Lenton, J. Bascompte, W. Brock, V. Dakos, J. Van De Koppel, I. A. van de Leemput, S. A. Levin, E. H. van Nes, M. Pascual, and J. Vandermeer. 2012. Anticipating critical transitions. Science 338(6105):344-348. http://dx.doi.org/10.1126/science.1225244

Schlüter, M., and E. Herrfahrdt-Pähle. 2011. Exploring resilience and transformability of a river basin in the face of socioeconomic and ecological crisis: an example from Amudarya River Basin, Central Asia. Ecology and Society 16(1):32. http://dx.doi. org/10.5751/es-03910-160132

Schuerman, M. 2015. Inside or outside? Two ways to protect Jamaica Bay. WNYC News, 19 March. [online] URL: http://www. wnyc.org/story/inside-outside-two-ways-protect-jamaica-bay/

Smith, A., and A. Stirling. 2010. The politics of social-ecological resilience and sustainable socio-technical transitions. Ecology and Society 15(1):11. http://dx.doi.org/10.5751/es-03218-150111

Solecki, W. 2016. Risk management policy transitions and transformational adaptation in social ecological systems. Abstract. Presented at the American Association of Geographers Annual Meeting, Chicago, Illinois.

Solecki, W., H. Link, and M. Garschagen. 2016a. Risk management and adaptation transitions in New York City. Journal of Extreme Events 03(03). http://dx.doi.org/10.1142/ $\underline{\mathrm{S} 2345737616500202}$

Solecki, W., C. Rosenzweig, S. Hammer, and S. Mehrotra. 2013. The urbanization of climate change: responding to a new global challenge. Page 197-220 in E. D. Sclar, N. Volavka-Close, and P. Brown, editors. The urban transformation: health, shelter and climate change. Earthscan, London, UK.

Solecki, W., C. Rosenzweig, S. Solecki, L. Patrick, R. Horton, and M. Dorsch. 2016b. New York, USA. Pages 169-184 in S. Bartlett 
and D. Satterthwaite, editors. Cities on a finite planet. Transformative responses to climate change. Routledge, London, UK.

Sultana, F., and A. Loftus. 2012. The right to water: prospects and possibilities. Pages 1-18 in F. Sultana and A. Loftus, editors. Right to water: politics, governance and social struggles. Earthscan, New York, New York, USA.

Tidball, K., and R. Stedman. 2013. Positive dependency and virtuous cycles: from resource dependence to resilience in urban social-ecological systems. Ecological Economics 86:292-299. http://dx.doi.org/10.1016/j.ecolecon.2012.10.004

Tollefson, J. 2013. Natural hazards: New York vs. the sea. Nature 494(7436):162-164. http://dx.doi.org/10.1038/494162a

U.S. Census Bureau. 2016. American fact finder. U.S. Census Bureau, Washington, D.C., USA. [online] URL: http://factfinder. census.gov/faces/nav/jsf/pages/index.xhtml

Vale, L. J. 2014. The politics of resilient cities: whose resilience and whose city? Building Research and Information 42(2):191-201. http://dx.doi.org/10.1080/09613218.2014.850602

Wallace, D., and R. Wallace. 2008. Urban systems during disasters: factors for resilience. Ecology and Society 13(1):18. http://dx.doi.org/10.5751/es-02386-130118

Warner, J. 2003. Risk regime change and political entrepreneurship. River management in the Netherlands and Bangladesh. Pages 185-198 in M. Pelling, editor. Natural disasters and development in a globalizing world. Routledge, London, UK.

Wilson, G. A. 2013. Community resilience, policy corridors and the policy challenge. Land Use Policy 31:298-310. http://dx.doi. org/10.1016/j.landusepol.2012.07.011

Wilson, S., L. J. Pearson, Y. Kashima, D. Lusher, and C. Pearson. 2013. Separating adaptive maintenance (resilience) and transformative capacity of social-ecological systems. Ecology and Society 18(1):22. http://dx.doi.org/10.5751/ES-05100-180122

Wise, R. M., I. Fazey, M. Stafford Smith, S. E. Park, H. C. Eakin, E. R. M. Archer Van Garderen, and B. Campbell. 2014. Reconceptualising adaptation to climate change as part of pathways of change and response. Global Environmental Change 28:325-336 http://dx.doi.org/10.1016/j.gloenvcha.2013.12.002

Wisner, B., P. Blaikie, T. Cannon, and I. Davis 2004. At risk: natural hazards, people's vulnerability and disasters. Routledge, New York, New York, USA. http://dx.doi.org/10.4324/9780203428764 